\title{
Literature Review: Culture Care Applications in Family First Aid to The Patients With Heart Attack
}

\author{
M. Sobirin Mohtar \\ \{sobirin@unism.ac.id*\} \\ Emergency Nursing Department, Sari Mulia University, Banjarmasin \\ *sobirin@unism.ac.id
}

\begin{abstract}
Arround $70.9 \%$ deaths caused by heart attacks due to family culture belief in traditional medication. Cultural care theory considers family tend to maintain their culture while doing the first aid, instead of looking for medical help. This issue need to be revised by the nurses. The aim of this study is to analyze articles which related to culture care applications in family first aid to the patients with heart attack. Literature review from several database including: Google Search, EBSCO, ScienceDirect and Proquest, has been done. It showed that delays were affected by several factors such as the belief of menyamak, angin $d u d u k$ and traditional treatment, cabut angin. Furthermore, the culture care applications provides nursing care including sunrise model assessment, nursing diagnosis, intervention, implementation and evaluation. This application could be applied to provide education to avoid misunderstanding in culture application especially in patients with heart attack.
\end{abstract}

Keywords: Culture Care Applications, family first aid, heart attack

\section{Introduction}

Heart attack remains one of the major causes of death in developed and developing countries which replaces deaths due to infection [5]. World Health Organitation [21] estimated that 17.5 million people died from a heart attack in which 7.4 million are estimated for Acute Coronary Syndrome and 6.7 million caused by the stroke.

Acute Coronary Syndrome (ACS) is a collection of coronary heart disease includes acute myocardial infarction (AMI), ST-Elevation Myocardial Infarction(STEMI), Non ST-Elevation Myocardial Infarction (NSTEMI) and Unstable angina pectoris (UAP) [8]. Rule out a diagnosis of ACS based on the symptoms of chest pain, changes in ECG results there as well as an increase in cardiac enzymes, especially of CK-MB and troponin T / I [3].

Among the many deaths caused by heart attacks due to delays in the family of nearly $70.9 \%$ [10]. It is influenced by education, knowledge, beliefs, emotions, previous experience at the time of the attack. Friedman familiy Theory considers that the family has the duty and the main function in decide on the action fast and tepat [7]. Teori Cultural care considers that the family have the tendency to maintain the culture at the time of rescue [12]. 
First aid family in ACS attack is very important in improving patient safety in this regard if not resolved will directly influence the biological, psychological, social and spiritual patient. Regarding the family culture in doing rescue, nurses need to do Cultural care with regard to the cognitive ability to know the values, beliefs and patterns of expression that is used to guide, support or allow individuals, families, or groups to maintain the health, healthy, thrive and survive, live within limitations and achieve a peaceful death [9].

Indonesia especially in Banjarmasin have social and cultural circumstances are different so care Culture Applications need to be applied in order to provide education related to cultural misunderstandings in action. Various nursing conceptual model is developed and applied to the patient, one model of care with the goal culture applications provide holistic services such as knowledge of heart attack should be given to the family and the importance of having plans to be prepared during the attack and play an important role in reducing delays in treatment when symptoms strike. based on the above background, the authors are interested discuss "Literature:Applications Culture Care in First Aid Families in patients with heart attack".

\section{Methods}

Writing articles in the literature search was conducted through the Google Search, EBSCO, ScienceDirect and Proquest by keyword Culture Care application, family first aid, heart attack, Literature search began in the year of publication between 2001-2018 for review. The inclusion criteria from the literature search is obtained from the journal to the type of researchsectional, fenomenological study and narrative analysis study, The criteria for the respondents in the literature review is Culture Care applications in the family first aid to patients with heart attack.

\section{Result}

The search results obtained literature articles numbered 35 and taken 22 articles in accordance with the inclusion criteria. Meanwhile, 13 articles were excluded because retrospective studies. Based on the results collected and analysis article writer found some problems in the first aid to patients with heart attacks that are arranged in a care culture applications, The following literature review of several studies: 


\subsection{Culture Care application in patients with heart attack}

\subsubsection{Culture Care Assessment}

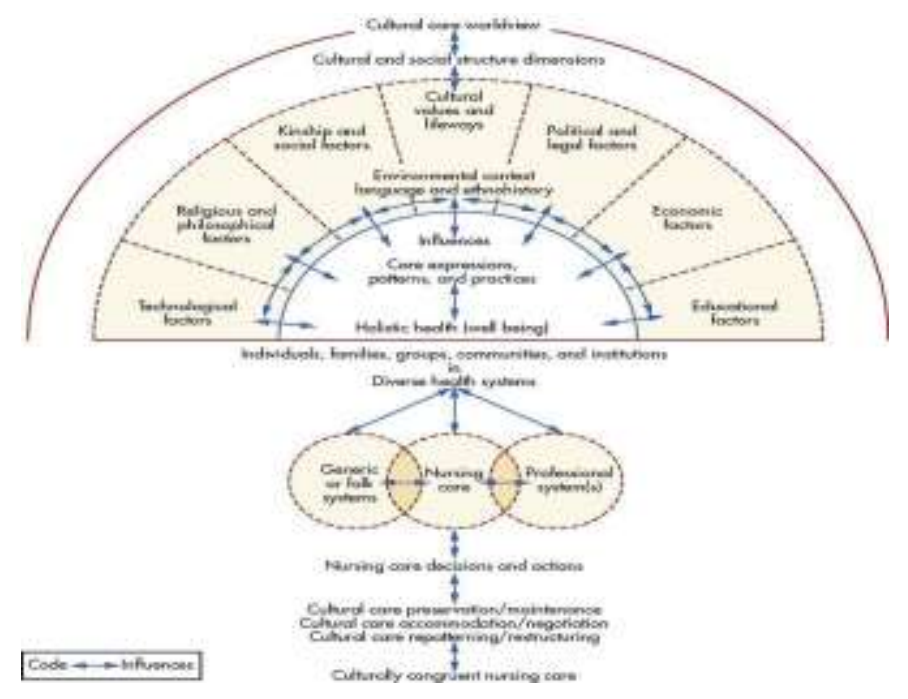

Fig. 1. Leininger's Sunrise Model basic chart

Some Literature explained that based on Figure 1. [12] outlines the results of the assessment associated with the use of culture care applications:

\subsubsection{Technology factor}

Assesment factor put forward by Leiningers technology; Sunrise Model That in this case the nurse needs assessment first act of what families do in helping patients with cardiac arrest in this case whether alternative actions or use of health services $[12,19,6]$. The use of alternative measures would be a factor of delay if a patient in distress kedaan, because the alternative kedaan emergency action will affectdistance and travel time to health services, both in terms of access to land, air and sea, it becomes a delay for patients with heart attacks. In line with the research reveals some receipts family alternative medicine by using whiting as the treatment of chest pain during an attack [22]. How it works take water squeezed lime juice, added a few whiting, salt and eucalyptus oil, water is rubbed on the chest. Along the study that betel been known and utilized by Indonesian society [15]. Betel pharmacopoeia has also been listed in the UK, France and India. Betel leaf contains amino acids, lysine, histidine and arginine. The betel leaf also contains essential oils (typical aromatic giver). On the treatment on 
traditional medicine, especially in treating pain betel leaves is known as aromatic substances so that the body can could of warm feeling was mapu block pain and prevent the pain spreads.

\subsubsection{Religion and Philosophy of Life factors}

Pengakajian Religion and Philosophy of Life presented by Leiningers; Sunrise Model that in this case the nurse needs religion professed mengakaji family and how the family way of life related diseases such as heart attacks in religion [12, 1, 19]. The traditional approach to disease prevention is centered around religion and belief, including practices such as burning candles, ritual atonement, and prayer. Religion greatly affect the way a person seeks to prevent disease, and religion plays a strong role in the rituals related to health protection. Religion practices outlined moral, social, and diet designed to keep adherents healthy and in balance. Religion also plays an important role in the perception of disease prevention on the devotees. For example, the Muslims, one alternative treatment is with prayer [20]. In the light of health, prayers contain deep psychotherapeutic elements. Psychoreligious this therapy is not less important compared with psychotherapy, psychoatric, as do "a spiritual power or spiritual containing that evokes a sense of confidence and optimism (hope of a cure). Confidence and optimism are the two things are very essential for the healing of an illness in addition to medicines and medical treatment given [1]. Psychoreligious this therapy is not less important compared with psychotherapy, psychiatric, as do "a spiritual power or spiritual containing that evokes a sense of confidence and optimism (hope of a cure). Confidence and optimism are the two things are very essential for the healing of an illness in addition to medicines and medical treatment given [1]. Psychoreligious this therapy is not less important compared with psychotherapy, psychiatric, as do "a spiritual power or spiritual containing that evokes a sense of confidence and optimism (hope of a cure). Confidence and optimism are the two things are very essential for the healing of an illness in addition to medicines and medical treatment given [1].

\subsubsection{Social and attachment Kinship factors}

Social and attachments Kinship Assesment proposed by Leiningers; Sunrise Model that in this case the nurse needs mengakaji attachment to family and community engagement with the patient as to see if there is an opinion that the elder in the treatment of patients with heart attack despite being opposed to health $[12,20]$. 


\subsubsection{Values Culture and Lifestyle factors}

Pengakajian Values Culture and Lifestyle family and patient proposed by Leiningers; Sunrise Model that in this case the nurse needs mengakaji isitiadat customs and habits of families that have been implemented to provide benefits to cure a disease which he thought was good and fast recovery $[12,20]$.

\subsubsection{Policies and Regulations applicable Hospital factors}

Pengakajian Policies and regulations that apply to the Hospital family and patients proposed by Leiningers; Sunrise Model that in this case the nurse needs mengakaji rules and regulations that have been issued by the health service and is kept by the family and the patient, because it will probably be a factor of delay aid if the rules and policies Chatter so that families and patients choose to use alternative medicine $[12,20]$.

\subsubsection{Economic factors}

Pengakajian economic against family and patients proposed by Leiningers; Sunrise Model that in this case the nurse needs income assessment month in financing the pain in order to get better soon, because it will probably be a factor of delay relief if health care is very expensive so the family and the patient opted to use alternative treatment they believe is cheap and affordable $[12,19]$.

\subsubsection{Education factors}

Pengakajian education family and patients proposed by Leiningers; Sunrise Model that in this case the nurse needs mengakaji level of education in order to support in assessing the knowledge of the family will be the illness of the patient, because it will probably be a factor of delay in assistance if the family considers that coronary heart disease nothing to do with culture or etnomedisine proven unscientific and irrational in this regard tanning disease (isitilan tribe banjo) and angina seating (Java rate terms) [12, 2, 11, $14,4,19,13]$.

\subsubsection{Culture Care Nursing Diagnosis}

Some Literature mentions four nursing diagnoses were often enforced Madeleine Leininger in care ie culture applications $[16,17]$. 
3.1.2.1 Impaired verbal communication related to cultural Incompatibility

1) Definition: The inability to receive or use the symbol / Language

2) Defining characteristics: difficulty in understanding communication, inability talking with caregivers and difficult to express words

3.1.2.2 Non-compliance in the treatment associated with the value system believed

1) Definition: Behavior that does not follow the plan of care / treatment agreed dg health workers

2) Defining characteristics: do not follow the advice, do not undergo treatment / medication and lifestyle changes.

3.1.2.3 Lack of knowledge related to cultural cognitive limitations to misinformation

1) Definition: Lack of cognitive information related to a specific topic

2) Defining characteristics: behavior is not as recommended, erroneous perception of the problem and underwent improper.

3.1.2.4 Tend to be risky health behaviors associated with less understanding / negative attitude towards health care / negative perceptions towards healthcare

1) Definition: Barriers ability to change lifestyle

2) Defining characteristics: Failing to prevent health problems, reducing health changes and does not accept changes in health status.

\subsubsection{Culture Care Nursing Interventions}

Some Literature 3 Nursing interventions are often made in the care and culture applications listed in Figure 1., namely (adjust to the patient's problems) [12]:

3.1.3.1 Cultural preservation care/ maintenance (Maintaining a culture)

1) Identify the conceptual differences between the client and the nurse about the complaints or diseases

2) Be calm and do not rush when interacting with clients

3) Discussing the cultural gaps that clients and caregivers

3.1.3.2 Cultural care accomodation / negotiation (Considering their culture)

1) Involve the family in care planning

2) If the conflict is not resolved, do the negotiations where agreement based on biomedical knowledge, client views and standards of conduct.

3.1.3.3 Cultural care repartening/ reconstruction (Fix culture)

1) Translate the definition of the patient's symptoms into medical language that can be understood by the client and family.

2) Provide information to the client about the health care system.

3) Use third parties if necessary.

4) Give the client a chance to understand the information provided and to implement. 
According to Families can carry out care or health care can be seen from the task of family health, as follows [7]:

1) Getting to know your family health problems Health is a family needs should not be overlooked

2) Making the decision to the appropriate health actions

This task is a major effort of families to seek appropriate relief in accordance with the state of the family, with consideration among family members who have the ability to decide an action.

3) Providing care to sick family members

Seringa time the family took the right decision, if my family still have limitations, then the family members with health problems need to obtain follow-up or treatment to be a more serious problem does not occur

4) Maintaining a healthy home atmosphere

Home meruapakn shelter, shelter and socializing for family members, so that family members will have more time dealing with the neighborhood. Therefore, housing conditions should support health status for family members

5) Using the existing health facilities in the community

Families can consult or request the assistance of kepearwatan to solve problems experienced by members of his family, so the family can be free from all kinds of diseases.

\subsubsection{Evaluation of Culture Nursing Care}

Some nursing Literature evaluation is often done in culture care applications to client success (outcomes) and are listed in Figure 1. is [12]:

3.1.4.1 Maintaining a culture conducive to health,

3.1.4.2 reduce the client's culture that is not conducive to health

3.1.4.3 Adapting to a new culture that may be contrary to the culture of the client.

3.1.4.4 It can be seen through the evaluation of nursing care in accordance with the client's cultural background.

\section{Discussion}

In accordance with one of the factors in the cultural dimension sunrise scheme Leiningers models that it is included in the component Technological Factors (Factors of Technology) where medical technology is a tool that allows people to choose or have a quote solve problems in health care [19]. In connection with the utilization of health technology, the nurse needs to examine include: the client's perception about the use and utilization of technology to manage health problems at this time, the reason for seeking health assistance, health-illness perceptions, habits treatment or health problems. The reason the client does not want the operation and the client chooses alternative treatments. Clients following the laboratory tests of blood and understand the meaning of the test results [20]. 
Religion is a system of symbols which resulted in the views and motivation is very realistic for the believer. Realistic nature is a characteristic of religion. Religion provides a strong motivation to put the truth above all else, even above his own life. Religious factor can be studied nurses, such as religious beliefs, religious practices that have a positive impact on health, endeavors to heal without knowing the desperate, have a concept of self intact, marital status, client perceptions on health and how to adapt to the current situation, client's perspective to the causes of disease, how the treatment and transmission to others [20].

In accordance with one of the factors of cultural dimensions in the scheme sunrise models Leiningers that it is included in the component Social factors and attachment Kinship (Kindship and Social Factors) wherein In social factors and familial needs to be assessed by the nurse is the full name and nickname in the family, age or place and date of birth, gender, status, family type, decision-making in the family, a client relationship with the head of the family, custom made routine by the family such as family gathering, the activities carried out together with the community, for example, join sports or study group [20, 19].

In accordance with one factor the cultural dimension in the scheme sunrise models Leiningers that it is included in the components of Cultural Values and lifeways (Factor Values Culture and Lifestyle) where value is conceptions abstract in man, about what constitutes a good and what is considered bad [19]. Cultural values is something that is defined and determined by the adherents of culture is considered good and bad. Norma is a social rule or standard of behavior that is considered appropriate. Cultural norms is a rule that has limited application to the adherent properties associated culture.

In accordance with one of the factors of cultural dimensions in the scheme sunrise models Leiningers that it is included in the components of the Political and Legal Factors (Factors of Policy and Regulation of Hospital applicable) to which the policy and hospital rules that apply are everything affect the activities of individuals and groups within nursing care transcultural, such as regulations and policies related to visiting hours, the client must wear a uniform, number of family members who may be waiting for, the rights and obligations of the client who must make a referral to the hospital and how to pay for clients are treated [19].

In accordance with one of the factors of cultural dimensions in the scheme sunrise models Leiningers that it is included in the component Economic factors (Economical Factors) which Client hospitalized utilizing material resources owned to finance the pain in order to get well soon. Economic resources which are generally used by clients such as: insurance, office expenses, savings and joint ventures between family members. Economic factors need to be assessed by a nurse is a client job, source of medical expenses, savings habits and the amount of savings in a month [19].

In accordance with one of the factors in the cultural dimension sunrise scheme Leiningers models that it is included in the Education component Factors (Factors Education) where the educational background of the client is the client experience in the path of the current highest formal education. In the process of education occurs an experimental process. A process to confront and resolve the problem that starts from the family and then resumed in education outside the family [12]. The higher education client then conviction must be supported by scientific evidence and rational can learn to adapt to the culture in accordance with the medical condition [19].

In line with the theory Friedman et al that the family should carry out care or health care can be seen from the family health task in this case to know the family's health problems make a decision 
for health action, building on the existing health facilities in the community, maintaining a healthy home atmosphere and provide care for sick family members [7].

Maintaining a culture done if the family culture and the health of the patient does not conflict with in this case if the families who have family members experiencing ACS attack action alternative medicine because it is against the patient in distress it must be done fast and precise action. Planning and implementation of nursing provided in accordance with the values that are relevant to what has been owned by the family, so the family can improve or maintain the health status of family members. In line with the theory of Leininger that the nurses should do Cultural Care Preservation or Maintenance namely the principles of aid, facilitate, or watching a cultural phenomenon to help individuals determine the level of health and desired lifestyle [9]. This principle also allows the actions and decisions that help keluaga and clients of a particular culture to maintain or preserve the values of the relevant treatment, so that they can be better, recovering from illness, or face disability or death. Nurses help families and clients to pick and choose other cultures are more supportive of improved health, for example, the client is offensive ACS nurse must negotiate and bargain to the family by way of a nurse while maintaining its culture as an alternative treatment just as the act of a side if necessary, mean in this case alternative measures may be done when family members recover from the attack and the rest when in distress that my family should be entrusted to health professionals such as medical treatment measures (assessment of pain, ECG and cardiac enzymes lab tests).

In line with the theory of Leininger that the nurses should do Cultural Care Accommodation or Negotiation Namely the principles of negotiation, support, help facilitate, or pay attention to the cultural phenomena that reflect the ways to adapt, enabling creative professionals actions and decisions to help the families of culture appointed to negotiate or consider the health and lifestyle of his family members [19]. Cultural restructuring is done when the culture of adverse health status. The nurse seeks to restructure lifestyle usually family members who smoke to not smoke. Life plan selected pattern is usually more profitable and in accordance with the beliefs held, because with one contributing factor is the onset of ACS attack poor lifestyle such as smoking and so forth

In line with the theory of Leininger that the nurses should do Cultural Care Repatterning or Restructuring That principle reconstruct or change the design to help improve health conditions and patterns of family life for the better. The restructuring process includes helping, supporting, facilitating or enabling professional actions and decisions that help families recast, transformed, or greatly modify their lifestyle to the pattern of health care that is new, different, and profitable, while still respecting cultural values and beliefs family [9].

Next nurses must adapt and adjust the need for culture in trust kelurarga patient and nurse studying it through nursing care at Sunrise Model approach. in step by Leininger's theory that nurses should do Culture Congruent / Nursing Care That is An awareness to adjust the values of culture or beliefs and way of life of individuals or groups or institutions in an effort to provide nursing care is beneficial [19]. 


\section{Conclusion}

There are various descriptions of the early recognition of the disease, the first action, the onset of relief, the delay factor, the emotional response and relief influential significance to patient safety. Based on the description above for individuals in families affected by ACS would largely provide first aid assistance participant in a different way so that if it is less precise manner and cause delay in providing help there will be disability or even death will occur. Family experience in providing first aid (first aid participant), especially in patients with ACS seragan is important because it needs help quickly began making a decision until the patient handled.

\section{Reference}

[1] Ali, Zaidin.: Agama, Kesehatan dan Keperawatan. Jakarta: CV Trans Info Media (2010)

[2] Anderson, G.B., \& Foster, G.M.: Antropologi Kesehatan (Terjemahan oleh Suryadama, P \& Swasono, M). Jakarta : UI-Press (2001)

[3] Cannon, C.P., \& Braunwald, E. Unstable Angina. In Braunwald: Heart Disease; A Textbook Of cardiovascular Medicine, 6th ed. WB Saunders Company.p.1232-1255 (2001)

[4] Dalusung \& Angosta. A.: Coronary Heart Disease Knowledge and Risk Factors among Filipino-Americans connected to Primary Care Services. University of Hawai at Manoa), 2010 ProQuest Dissertations and Theses, Retrieved from. fulltextPDF/13505E0921D601FE1A6/13 (2010)

[5] Depkes RI. Jakarta : Badan Penelitian dan Pengembangan, Departemen Kesehatan RI (2013)

[6] Farshidi et al:: Factors Associated With Pre-hospital Delay in Patients With Acute Myocardial Infarction. Iranian Red Crescent Medical Journal. Iran Red Crescent Med J. 2013;15(4) (2013)

[7] Friedman, M.M.: Family Nursing : Research Theory, Practice. 5th edition. Prentice Hall, New Jersey (2010)

[8] Gayatri et al. Prediktor Mortalitas Dalam-Rumah-Sakit Pasien Infark $\quad$ Miokard $\quad S T$ Elevation (STEMI) Akut di RSUD dr. Dradjat Prawiranegara Serang, Indonesia. CDK238/ vol.43 no.3, th. 2016 (2016)

[9] Gonzalo, Angelo G. Madeleine M. Leininger-Theoretical Fondation of Nursing. Dalam http://nursingtheories.weebly.com/madeleine-m-leininger.html (ditelusuri tanggal 27 Januari 2018, Pukul 07:44) (2018)

[10] Herning et al.: Women's experiences and behavi our at onset of symptoms of ST segment elevation acute myocardial infarction. Elsevier. M. Herning et al. /European Journal of Cardiovascular Nursing 10 (2011) 241-247 (2011)

[11] Kelly. T and Howie, L.: Working with stories in nursing research: procedures used in narrative analysis. International journal of mental health nursing,16,136-144 doi :10.1111/J.1447-0349.2007.00457.x (2010)

[12] Leininger, Medeleine M. Transcultural Nursing: Concept. Theorist. Research \& Practice. $3^{\text {rd }}$ Edition. USA: McGraw-Hill (2001)

[13] Manggia.: Penyakit Jantung Kerap disebut Angin duduk. Suara Merdeka [on-line].(2017). 
[14] Mansour.: Kapita Selekta Kedokteran. Edisi Ketiga. Jakarta: Media Aesculapius FKUI (2010)

[15] Mulyono.: Khasiat dan Manfaat daun sirih: Obat Mujarab dari masa ke masa. Jakarta: Agro Media Pustaka (2005)

[16] Nanda.: Nanda-I Diagnosis Keperawatan: Definisi dan Klasifikasi 2018-2020. Jakarta: EGC (2018)

[17] PPNI.: Standar Diagnosis Keperawatan Indonesia: Definisi dan Indikator diagnostik. Edisi 1 (2017)

[18] Pratiwi,: dkk. Komplikasi pada Pasien Infark Miokard Akut ST-Elevasi (STEMI) yang Mendapat maupun Tidak Mendapat Terapi Reperfusi. Jurnal Kardiologi dan Kedokteran Vaskuler RSUP Dr.Kariadi Semarang (2011)

[19] Pratiwi.: Buku Ajar Keperawatan Transkultural. Yogyakarta: Gosyen Publishing (2011).

[20] Sutria.: Keperawatan Transkultural. Makassar: Alauddin University Press (2013)

[21] World Health Organitation. Angka Mortalitas Penyakit Kardovaskuler. (2015)

[22] Widyawati dkk.: Empowering the urban medicinal garden through descriptions and benefits of medicinal plants. PROS SEM NAS MASY BIODIV INDON. Volume 1, Nomor 8, Desember 2015 ISSN: 2407-8050. Hal: 1890-1895. DOI: 10.13057/psnmbi/m010823 (2015) 